\title{
To What Extend do the Migrant's Remittances Affect on the Economic Growth in Jordan
}

\author{
Al Jaidi Nidal \\ Department of Business Economics, Business School, University of Jordan, Amman, Jordan \\ Email address: \\ Nidal.aljaidi@gmail.com \\ To cite this article: \\ Al Jaidi Nidal. To What Extend do the Migrant's Remittances Affect on the Economic Growth in Jordan. International Journal of Business \\ and Economics Research. Vol. 8, No. 6, 2019, pp. 364-368. doi: 10.11648/j.ijber.20190806.15
}

Received: January 29, 2019; Accepted: September 6, 2019; Published: October 16, 2019

\begin{abstract}
The magnitude of a huge number of remittances which comes from individuals or from foreign direct investments that flow on the economies of developing countries during the last few decades cannot be ignored, and especially on Jordanian macroeconomic, where it is not considered as an industrial or oil country, but it is characterized by a human resources wealth. The revenues of these resources are considered to be one of the main pillars on the Jordanian economy. While, these human resources divided into two parts, some of them tend or choose to work inside the country and others tend to work abroad. On another level, The Kingdom of Jordan seeks to attract the foreign investment despite of some obstacles and conditions. Hence, the problem stems from the extent of the impact of migration revenues and foreign direct investment on Jordanian economic growth. So this study will examines the effects of remittances and FDI on the growth of Jordanian GDP using a time series data during 1980-2015, and then assess the relative importance and the interaction of both. The result of this study showed a long-run relationship of the impact of remittances and the foreign direct investment on gross domestic product growth. Whereas, the impact of foreign direct investment is greater than the impact remittances on GDP, while the study found a lack of causality between these variables in the short-term period.
\end{abstract}

Keywords: Jordan, Remittances, Economic Growth, Migrant, Foreign Direct Investment, Gross Domestic Product

\section{Introduction}

Emigration is a continuous phenomena for developing countries, since it sets a series of factors among which the outflow of foreign exchange in the form of migrants' remittances. Remittances are considered to be the basic gain of migration for the emigration countries and their main compensation for losing a part of their labor force. Remittances can be defined as interpersonal transfers between migrants and their families remained in their country, According to IMF remittances includes three categories: Compensation to employees comprise wages, salaries, and other remuneration, in cash or in kind, paid to individuals who work in a country other than where they legally reside. In addition, to the workers' remittances refer to current transfers by migrants who are employed in new economies and considered residents there. Finally, the remittances include Migrants' transfers that refer to capital transfers of financial assets which made by migrants as they move from one country to another and stay for more than one year [3].
All around the world, the total remittances that sent from migrants to their developing countries were more than US\$325 billion. While the foreign direct investment (FDI) was only US\$167 billion, and with three times larger than official development assistance (ODA) which received US $\$ 104$ billion. This, makes the remittances a more stable and less volatile source of external finance rather than foreign direct investment (FDI) and official development assistance (ODA) [17].

Remittances are the prime earner of the foreign exchange that followed by tourism in Jordan, which received some $\$ 30.6$ billion from the inflow of emigrant during the period 1970 2002. Where found as the third largest remittance receiving country in the Middle East after Egypt and Morocco [19].

We have to know that the impact of remittances on economic growth can be either positive or negative in the country of origin. A study of nonlinear growth effect of remittances in Bangladesh during 1974-2006 shows that the remittances effect negatively on economic growth at the beginning, then it becomes positive at later stage (Hassan and 
others, 2012). As far as, there is a study done in 2014 on two small transition countries Moldova and Albania showing that the positive effects of remittances could be reinforced while negative ones should be mitigated [9].

Moreover, there is a study done in 2014 on Algeria shows that the remittances have a negative impact on economy in both short and long term, since the increase in remittances by $1 \%$ will lead to a decline in GDP per capita by $0.02 \%$ in the short term, also by $0.006 \%$ in long term. This means that the countries can promote the rerouting of remittances towards productive investments by eliminating the governmental distortions and market failures. On the other hand, they can sterilize the inflow of foreign currency to prevent Dutch disease problems and at the same time to implement an industrial policy and stabilization funds [18].

Interestingly, there is a study done in 2008, improved that modern remittances are very important to origin country which promote the economic growth of the poorest nations [17]. Another study is inducted at South Asia in 2012 and supported the positive effect by indicating that, migration remittances are found to have a significant positive effect on economic growth which is detected through education and financial sector development [16]. In the same region, there is another study on remittances growth and poverty done in 2012, highlighted that remittances flows will increase growth of economy and will reduce poverty through increasing income, which encourage greater investment on physical assets, education and health [14].

Depending on literature review, it is notified that remittances have two side effects, positive effects related to contribute in poverty reduction, economy growth, foreign currency, education, healthcare, and other sectors. In addition, the negative sides related to the loss of many of the skilled people, and this leads to loss many of competencies which need in the economy development.

Therefore, related to the above this paper aims to contribute the macroeconomic effects of remittance on the Jordanian economy growth over the period (1980-2015), and assess the relative importance and the interaction of both on GDP.

\section{The Data, Methodology and Results}

The source data of this research comes from the world value survey (WVS) and from the central bank of Jordan (CBJ). Whereas, the study have three variables which are: the endogenous variable is economic growth which data obtained from $\mathrm{CBJ}$, and the exogenous variables which are remittances and foreign direct investment (FDI) that data have collected from WVS.

Accordingly, the statistical analysis involves three main parts. The first part is a descriptive statistic analysis which involves some comparisons between the study variables in the terms of the time period yearly from 1982 to 2015 . The second part involves the testing of integration for each variables and the co-integration for the whole model. While, the third part focuses on correction and estimation of an equation that expresses the economic growth rate at Jordanian level as a function remittances and FDI as a rate.

Based on our discussion, the model drawing as follow:

$$
\operatorname{GGDP}_{\mathrm{t}}=\alpha+\beta_{1} \mathrm{REM}_{\mathrm{t}}+\beta_{2} \mathrm{FDI}_{\mathrm{t}}+\varepsilon_{\mathrm{t}}
$$

Where:

GGDP: is a Growth rate of Gross Demotic Product.

REM: is a remittances.

FDI: is a Foreign Direct Investment.

Table 1. Descriptive Statistic.

\begin{tabular}{llllll}
\hline Variable & Mean & Median & Maximum & Minimum & Std. Dev. \\
\hline GGDP & 0.042 & 0.038 & 0.186 & -0.134 & 0.046 \\
REM & 0.167 & 0.175 & 0.248 & 0.090 & 0.044 \\
FDI & 0.046 & 0.028 & 0.235 & -0.006 & 0.056 \\
\hline
\end{tabular}

In Table 1 we report a descriptive statistics for all the dependent and independent variables, Table 1 reveals the following comments.

First, the mean of Growth rate of Gross Demotic Product is equal to 4.2 percent. In addition, this variable had a maximum value of 18.6 percent and a minimum value of minus 13.4 percent. This big variation has a critical reason when we look at chart 1 below we obviously can see the distance between 1988 and 1990 during this period and specially in 1988, the Jordanian dinar has suffered from the collapse. But, after 1990, the Jordanian economy grew significantly because of the return of Jordanian expatriates from Kuwait.

As well as, when we look at the independents variables, the maximum and minimum values of remittances are equal to 24.8 percent and 9 percent, and on FDI are 23.5 percent and -.06 percent, respectively. Indeed, the difference between these two variables in terms of respective standard deviations reveals that. As chart 2 proof what has happened on GGDP through remittances reduction in that period that mentioned.

To examine the existence of stochastic non-stationary in the series, this paper establishes the order of integration of individual time series through the unit root tests by using Augmented Dickey Fuller (ADF). The results of ADF have been presented in table 2 have indicated that the GGDP is stationary at level, but REM and FDI have a unit root problem. Fortunately, these two variables have become stationary at first difference, and the problem of unit root has disappeared from them. 


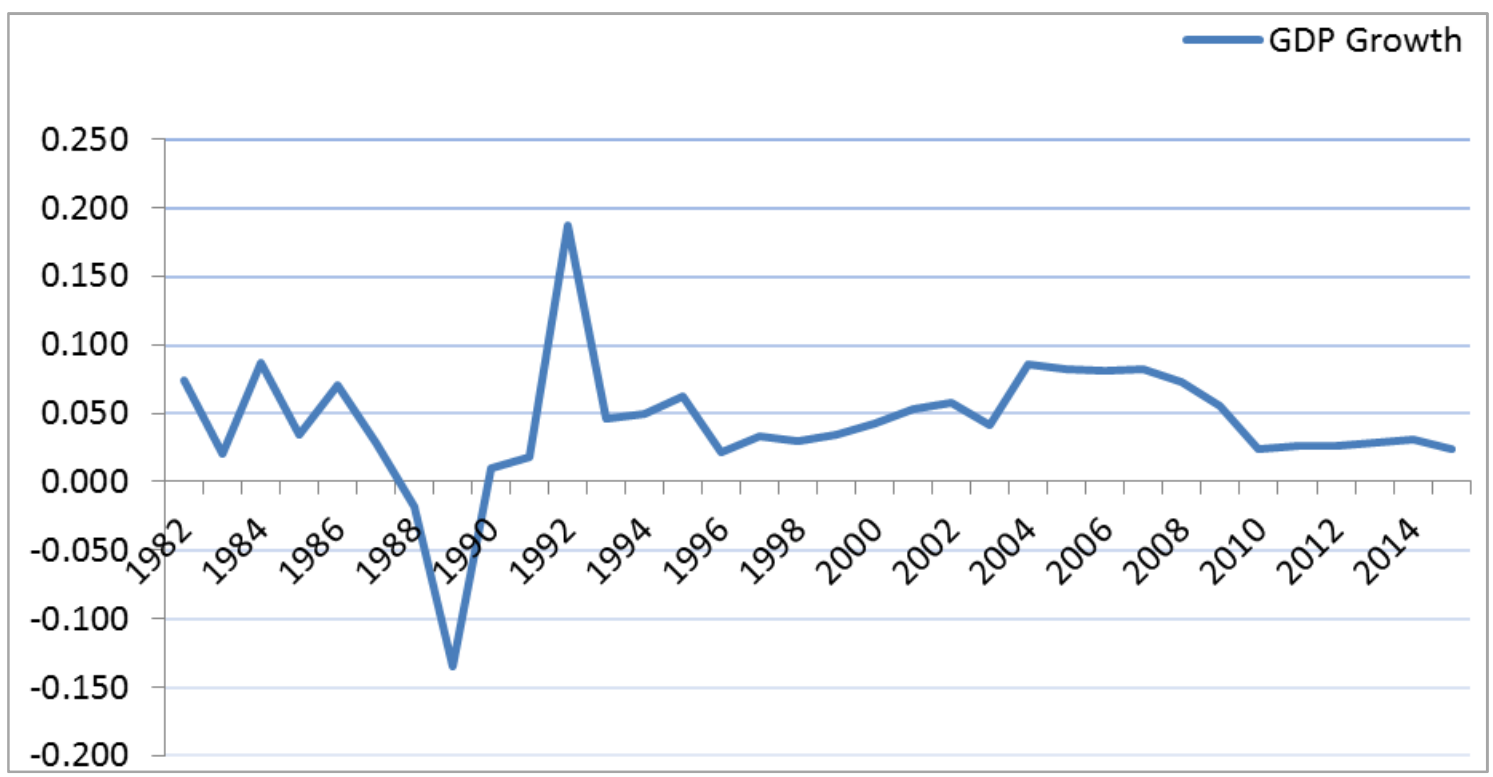

Figure 1. Growth rate of Jordanian Gross Demotic Product.

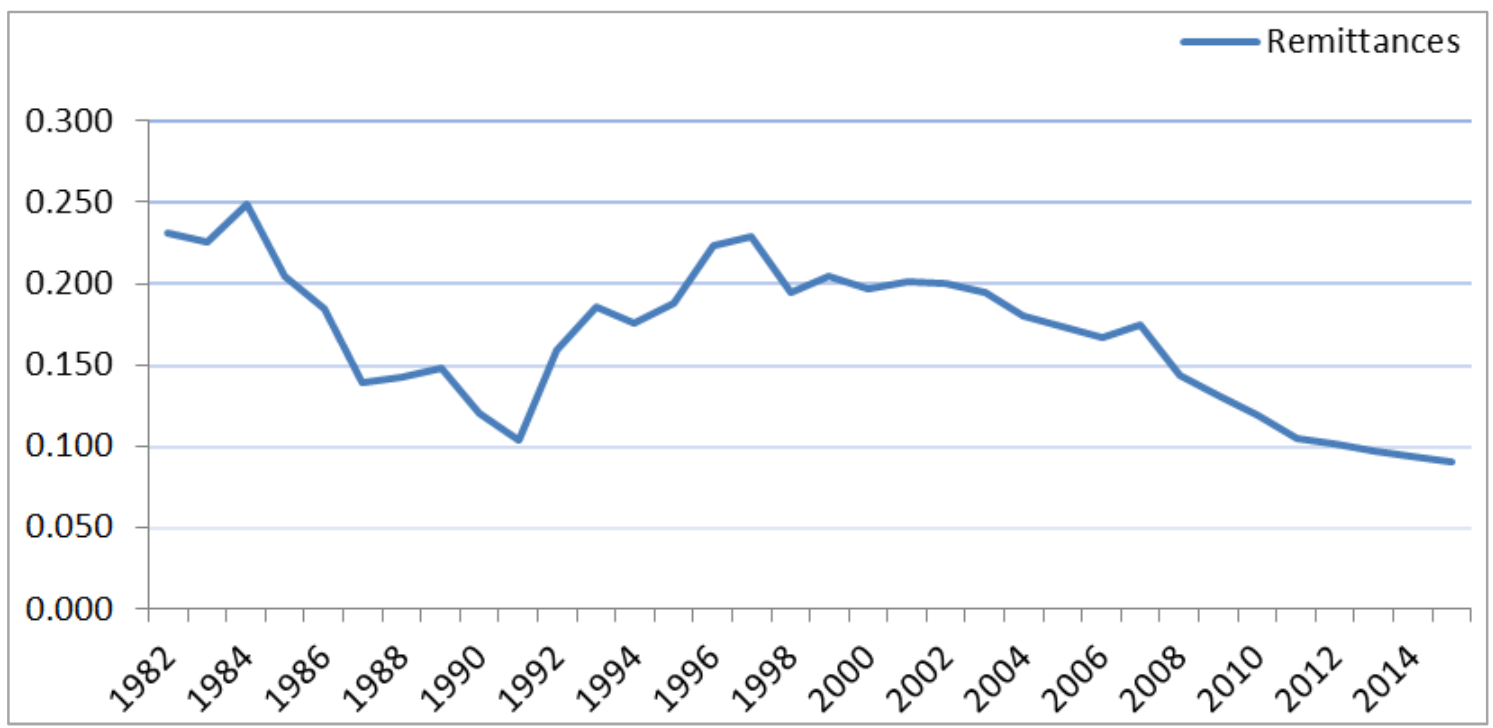

Figure 2. Jordanian Remittances.

Table 2. Augmented Dickey-Fuller (ADF) Test for Unit Root.

\begin{tabular}{lllll}
\hline \multirow{2}{*}{ Variables } & At Level & \multicolumn{3}{c}{ At 1st Difference } \\
\cline { 2 - 5 } & T-statistics & P-values & T-statistics & P-values \\
\hline GGDDP & -4.056 & 0.0037 & -8.593 & 0.0000 \\
REM & -1.208 & 0.6587 & -5.064 & 0.0002 \\
FDI & -1.897 & 0.3294 & -5.815 & 0.0000 \\
\hline
\end{tabular}

Mackinnon approximate p-value (5\%)

Now, to test the co-integration and based on previous ADF test, the first difference was taken for the model. Accordingly, Trace statistic as mentioned on Table 3, the null hypothesis stating that there is no co-integration has rejected as the tracetest statistics $(51.9828,26.0586,09.9995)$ is greater than its critical value $(29.7970,15.4947,3.8414)$. Respectively, at 5 percent level of significance, this implies that all the variables are co-integrated, also they have long run association at first difference. Which means that, Growth GDP and other two explanatory variables move closely together to achieve the long run equilibrium as it's clear in graph 3.

Table 3. Johansen tests of co-integration.

\begin{tabular}{lllll}
\hline Unrestricted Co-integration Rank Test (Trace) & & & \\
\hline & Eigenvalue & Trace Statistic & $\mathbf{0 . 0 5}$ Critical Value & Prob. \\
\hline None & 0.5666 & 51.9828 & 29.7970 & 0.0000 \\
At most 1 & 0.4043 & 26.0586 & 15.4947 & 0.0009 \\
At most 2 & 0.2757 & 09.9995 & 03.8414 & 0.0016 \\
\hline
\end{tabular}

Mackinnon approximate p-value (5\%) 


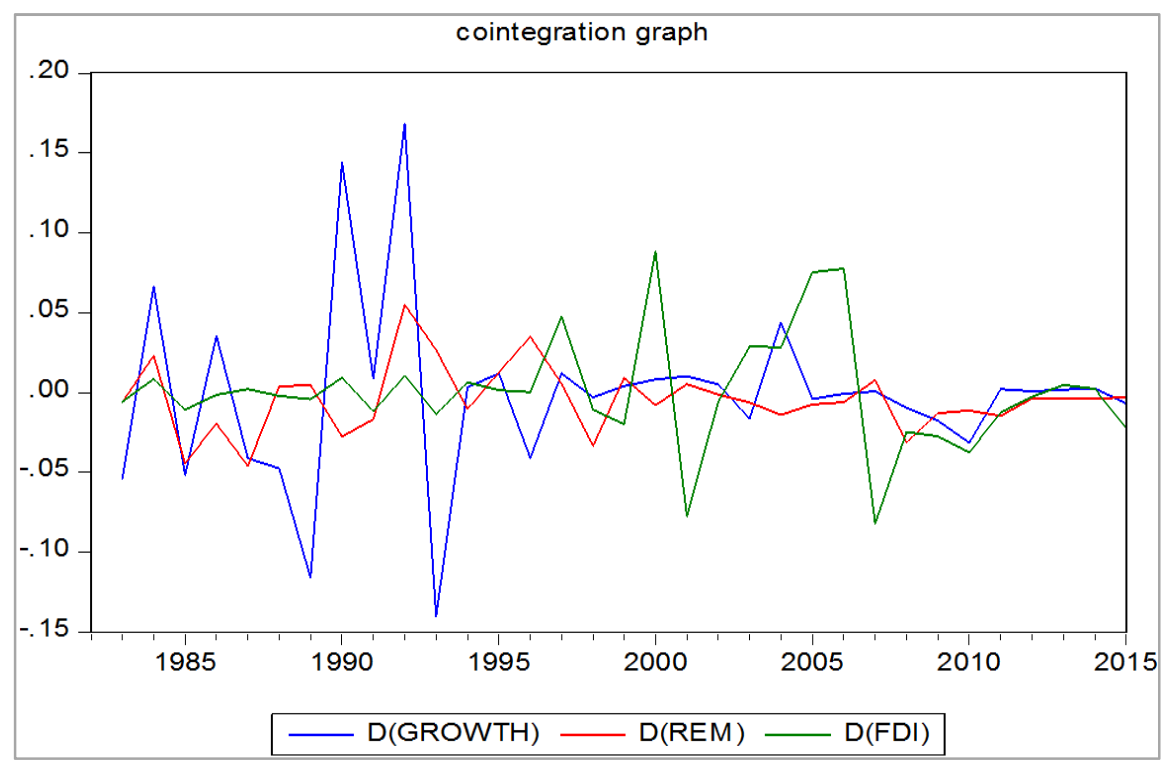

Figure 3. Model Cointegration.

Under Co-integration circumstances, there are long term and stable co-integration relationship at first difference between the three variables of the model. Now, to insure the causality between these variables at short run, we will use a granger causality test as it described in Table 5.

Table 4. Granger Causality Tests.

\begin{tabular}{lllll}
\hline \multirow{2}{*}{ Null Hypothesis } & At level & & At first difference \\
\cline { 2 - 5 } & f-statistic & Prob & f-statistic & Prob \\
\hline REM does not Granger Cause GGDP & 0.44206 & 0.6473 & 1.48500 & 0.2451 \\
GGDP does not Granger Cause REM & 0.29463 & 0.7472 & 3.05213 & 0.0645 \\
FDI does not Granger Cause GGDP & 0.27604 & 0.7609 & 0.11723 & 0.8898 \\
GGDP does not Granger Cause FDI & 0.21966 & 0.8042 & 0.20148 & 0.8188 \\
FDI does not Granger Cause REM & 0.84640 & 0.4400 & 0.27636 & 0.7607 \\
REM does not Granger Cause FDI & 0.37288 & 0.6922 & 0.43744 & 0.6504 \\
\hline
\end{tabular}

Table 5. Vector Error Correction Estimates.

\begin{tabular}{llll}
\hline \multirow{2}{*}{ Error Correction } & \multicolumn{3}{l}{ First difference of GGDP } \\
\cline { 2 - 4 } & Coefficient & Standard error & t-statistic \\
\hline Residuals & -1.4865 & 0.2283 & -6.5088 \\
\hline
\end{tabular}

Actually, under the previous result, the Granger causality test at the level shows that there is no any short run relationship among variables for both directions. Where, causality is not significant as it is described. Moreover, at first, the difference study find out that there is only one directional Granger causality exist, where GDP GROWTH has Granger Cause Remittances at 10\% significance level, while other causality test does not appear.

As a matter of fact, because there is Co-integration exist at the first difference. Thus, a vector error correction model (VECM) has to be included in, which gives us the long-run structural relations that is showing in Table 6 Consequently, there is stable long run relationship for the model. Whereas, the coefficient sign is negative and the t- statistic is significant.

Table 6. Fully Modified least squares.

\begin{tabular}{lllll}
\hline Dependent Variable: GDP Growth & & & \\
\hline Independent Variables & Coefficients & Standard Errors & t-Statistics & Prob \\
\hline Remittances & 0.19022 & 0.05213 & 3.6491 & 0.0010 \\
Foreign direct investment & 0.31938 & 0.12226 & 2.6122 & 0.0137 \\
R-squared & 0.139 & Adjusted R-squared & & 0.112 \\
\hline
\end{tabular}

On the basis of VEC model results, co-integrating regression is estimated. In the situation, where the series are co-integrated at first difference (1), fully modified ordinary least square (FMOLS) is suitable for the estimation to provide optimal estimates of co-integrating regression. Depending on the result on Table 7, we found there is A significant affect for both independent variables on economic growth at 5\% significance level. Otherwise, by increasing one value of remittances the growth of GDP will increase by 0.19 of value, and increasing of FDI by one value the growth of GDP will increase by 0.32 of value.

The analysis of the dynamic interactions among the variables through variance decompositions, and to put it more simply as it is cleared on Table 8 , both remittances and 
FDI have a positive effect on economic growth throw years. While, remittances has a stronger effect on Economic growth where its variance decomposition is growing more than FDI.

Table 7. Variance Decomposition of first difference of GDP Growth.

\begin{tabular}{ll}
\hline first difference of GDP Remittances & first difference of GDP FDI \\
\hline 0 & 0 \\
0.001905 & 1.823369 \\
2.713628 & 4.869648 \\
12.08083 & 6.255624 \\
13.89897 & 6.099615 \\
16.39022 & 6.885573 \\
18.70339 & 7.556604 \\
20.87868 & 7.735949 \\
22.58635 & 7.943401 \\
23.83131 & 8.15506 \\
\hline
\end{tabular}

\section{Conclusion}

After presenting the problem of the study and the analysis of data statistically, the results showed that, a long-run relationship between the economic growths in Jordan. This growth is the growth of gross domestic product and between workers' remittances and foreign direct investments, since this relationship is a stable relationship to all variables of the model, where the increasing in Workers' remittances and foreign direct investment will lead to increases in economic growth in Jordan. But the results showed that, the impact of foreign direct investment is stronger than the effect of remittances on Jordanian GDP growth. Finally, the results showed absence of a short-run relationship between GDP growth and worker remittances and foreign direct investment, which showed that none of them is considered as the cause for the formation of any other variables in the short term.

\section{References}

[1] S. Hasan, R. Akhter, A. Al Abbasi, S. Saha "Impact of Remittance on Economic Growth in Bangladesh," American Journal of Trade and Policy, vol. 5, pp. 95-102, 2018.

[2] D. Peković, "The effects of remittances on poverty alleviation in transition countries," Journal of International Studies, vol. 10, pp. 37-46, 2017.

[3] S. Tabit, and C. Moussir, "The Impact of Migrants' Remittances on economic Growth: Case of Morocco," International Journal of Innovation and Applied Studies, vol. 20, pp. 226-233, 2017.

[4] S. Abdelhadi, and A. Bashayreh, "Remittances and Economic Growth Nexus: Evidence from Jordan," International Journal of Business and Social Science, vol. 8, pp. 98-102, 2017.

[5] D. Uprety, "The Impact of Remittances on Economic Growth in Nepal," Journal of Development Innovations, vol. 1, pp. 114-134, 2017.
[6] D. Uprety, and K. Sylwester, "The Effect of Remittances upon Skilled Emigration: an empirical study," Journal of economic development, vol. 42, pp. 1-16, 2017.

[7] T. Tolcha, and P. Rao, "The Impact of Remittances on economic Growth in Ethiopia," Indian Journal of Commerce \& Management Studies, vol. 20, pp. 01-15, 2016.

[8] O. Fayomi, D. Azuh, and L. Ajayi " The Impacts of Remittances on Nigeria's Economic Growth: A Study of Nigerian Diasporas in Ghana," Journal of South African Business Research, Vol. 2015, Article ID 598378, DOI: 10.5171/2015.598378, 2015.

[9] Bloushoutzi, and C. Nikas, "Emigrants' Remittances and economic growth in small transition economies: the case of Maldova and Albania," Journal of Economics and Business, vol. XVII, pp. 97-117, 2014.

[10] M. Shafqat, A. Ahmadm andS. Bano, "mpact of Worker Remittances on Economic Growth of Pakistan: Analysis of Pakistan's Economy," Journal of Business research Turk, vol. 6, pp. 6-14, 2014.

[11] Belmimoun, M. Kerbouche, L. Abouka, and R. Mokeddem, "The Impact of Migrants` Remittances on Economic Growth Empirical study: case of Algeria," European Scientific Journal, vol. 10, pp. 364-378, 2014.

[12] D. Ratha, "The Impact of Remittances on economic Growth and Poverty Reduction," Migration Policy Institution, vol. 15, pp. 1-14, 2013.

[13] D. Akonji, and A. Wakili, "The Impact of net Migrant Remittance on economic growth: Evidence from Nigeria," International Journal of Humanities and Social Science, vol. 3, pp. 303-315, 2013.

[14] K. Imai, R. Gaiha, A. Ali, and N. Kaicker, "Remittances Growth and Poverty: New evidence from Asian countries" International fund for agricultural Development, pp. 1-35, 2012.

[15] G. Hassan, S. Shakur, and M. Bhuyan, "Nonlinear Growth effect of remittances in recipient countries: An econometric analysis of remittances-growth nexus in Bangladesh" Annual NZAE Conference of New Zealand Association of Economists, pp. 1-35, 2012.

[16] A. Cooray, "The Impact of Migrant remittances on Economic growth: evidence from south Asia" Review of international economics,"vol. 20, pp. 985-998, 2012.

[17] M. Goldberg, M. and Levi, "The Impact of Remittances on Economic Growth" Mastercard worldwide insights, pp. 1-21, 2008.

[18] A. Culiuc, "Integrating migration and remittances into a development strategy, The case of Moldova" Master thesis at Harvard University, pp. 1-49, 2006.

[19] M. El-Sakka, "Migrant Workers' Remittances and Macroeconomic Policy in Jordan" Department of Economics, Kuwait University, available at www.semanticscholar.org, pp. $1-22,2005$. 